\title{
The Acetone Indigo Red Dehydrating Agent IF203 Induces HepG2 Cell Death Through Cell Cycle Arrest, Autophagy and Apoptosis [Retraction]
}

Shang Y, Wang Q, Li J, et al. Onco Targets Ther. 2020;13:473-486.

The Editor and Publisher of OncoTargets and Therapy wish to retract the published article.

The journal was notified of significantly similar images and data published in a previous article by the same authors:

IF203 induced apoptosis in human liver HepG2 cells through mitochondrial pathway. Acta Anatomica Sinica. 2011;42:340-344 (http://jpxb.bjmu.edu.cn/EN/10.3969/j. issn.0529-1356.2011.03.010).

It was found the following images and data appeared to be duplicated across both articles, with no satisfactory explanation provided by the authors:

- Figure $1 \mathrm{~B}$ in the recent article appeared to be the same as Figure 2 in the previous publication
- Figure $3 \mathrm{E}$ in the recent article appeared to be the same as Figure 3 in the previous publication

- Figure $3 \mathrm{C}$ in the recent article appeared to be the same as Figure 4 in the previous publication

- Figure $3 \mathrm{E}$ in the recent article appeared to be the same as Table 2 in the previous publication

The authors were also unable to provide the original raw data for the western blots shown in Figure 6. The editor determined the findings of the study were not supported and requested for the article to be retracted.

The authors wish to apologise for this error.

Our decision-making was informed by our policy on publishing ethics and integrity and the COPE guidelines on retraction.

The retracted article will remain online to maintain the scholarly record, but it will be digitally watermarked on each page as "Retracted".

\section{Publish your work in this journal}

OncoTargets and Therapy is an international, peer-reviewed, open access journal focusing on the pathological basis of all cancers, potential targets for therapy and treatment protocols employed to improve the management of cancer patients. The journal also focuses on the impact of management programs and new therapeutic agents and protocols on patient perspectives such as quality of life, adherence and satisfaction. The manuscript management system is completely online and includes a very quick and fair peer-review system, which is all easy to use. Visit http://www.dovepress.com/ testimonials.php to read real quotes from published authors. 